\title{
George Muirhead, LL.D.
}

\author{
(1845-1928).
}

George Muirhead, a fine type of the old-fashioned naturalist of the country, was born at Salton in East Lothian, where his father was a farmer. He was a lover of the country from his youth up, and added to the lore of the sportsman, the precision of the ornithologist and the botanist. His life was practically spent as a factor, beginning in Berwickshire, afterwards to the Marquis of Aberdeen at Haddo, and finally, for many years (1897-1923), as commissioner to the Duke of Richmond and Gordon at Fochabers. In his business relations he was held in universal respect, and he won the affection of all who had the privilege of his friendship. His beautiful book on the Birds of Berwickshire, published in two volumes in 1889 and 1895, which occupied him as a labour of love for many years, is one of the best of its kind; and he certainly had a very intimate familiarity with birds and their ways. He was also much interested in fresh-water fishes-in salmon in particular-and published in the Transactions of this Society and elsewhere some interesting observations on the influence of temperature and the like on spawning and development. His love of flowers and trees was almost a passion, and he had a wonderfully beautiful garden on the banks of the Spey at Fochabers. His knowledge of rock-plants in particular was very thorough, and he had the reward of great success with his cultivations. His curiosity with regard to the puzzles of natural history was unbounded, and even after fourscore years he continued, though with dimmed eyes, observing and inquiring, pondering and observing again. Thus he gathered a rich store of interesting information about the ways of living creatures, and it was a great pleasure to listen to his talk. He was elected a Fellow of the Royal Society of Edinburgh in 1888.

Mr Muirhead had a striking presence; he stood over six feet in height, erect and handsome. He lived a very active life, much in the open air, and he enjoyed everything to the end. His first wife, Agnes Grieve Clay, a daughter of the late Mr John Clay of Kerchesters, Berwickshire, had remarkable talent as a painter of birds, and they had three sons, two surviving. Mr Muirhead married again, in 1907, the Hon. Katherine Forbes Sempill, eldest daughter of the late Lord Sempill, 
who shared all his enthusiasms and scientific interests, and who survives him. In April 1925 the University of Aberdeen conferred on $\mathrm{Mr}$ Muirhead the degree of Doctor of Laws, in recognition of his contributions to the Natural History of Scotland and his success in worthily carrying on, in a quiet and unassuming way, the tradition of White of Selborne

J. A. T. 